\title{
The emotional competencies of the tennis
} coach

\author{
Josep Campos (Catalan Tennis Federation - Ramón Llull University, Spain), Miguel Crespo (ITF) \& \\ Enric Sebastiani (Ramón Llull University, Spain) \\ ITF Coaching and Sport Science Review 2015; 65 (23): 35-37
}

ABSTRACT

Professional and personal competencies are valid indicators to evaluate productive and human processes. Competencies are also a reference for the development of individuals, groups and organisations that are developed before and during the professional working commitments. This article discusses the main concepts related to the emotional competencies of a tennis coach and stresses their importance in daily work.
Key words: tennis coach, professional competencies, emotional competencies

Received: 1 February 2015

Accepted: 15 March 2015

Corresponding author:

Josef Campos

Email:

josepcr@blanquerna.url.edu

\section{INTRODUCTION}

Gallwey (1974), stated that "a good coach can help the athlete to reach harmony between the body and the mind", and that a common problem for coaches has been to learn "how to give instructions fostering the natural learning process for the student without interfering in it "(p. 96).

There have been several authors including Zeigler \& Bowie (1983) that have proposed a number of skills that must be possessed by the coach in order to be successful at the personal and relational level. These skills are:

- Personal skills: to organise their own work in reference to their professional competence.

- Relational skills: to impact the group of people who are working with them, and to motivate them towards a common target.

Then, Martens, Christina, Harvey \& Sharkey (1989) identify three fundamental qualities for a sport coach, combining conceptual, personal and social elements.

- Knowledge of the sport: techniques, rules, strategies.

- Motivation: to enjoy the activities

- Empathy: to be able to understand the feelings, thoughts and emotions of the athletes.

A coach's empathy is the capacity to understand the athlete; it is considered an element of vital importance (Lorimer, 2013).

Emotional competencies

Bisquerra \& Pérez (2007) have explained that emotional competencies are an important and relevant element among the professional competencies of coaches and have divided the competencies into two categories, socio-personal and technical-

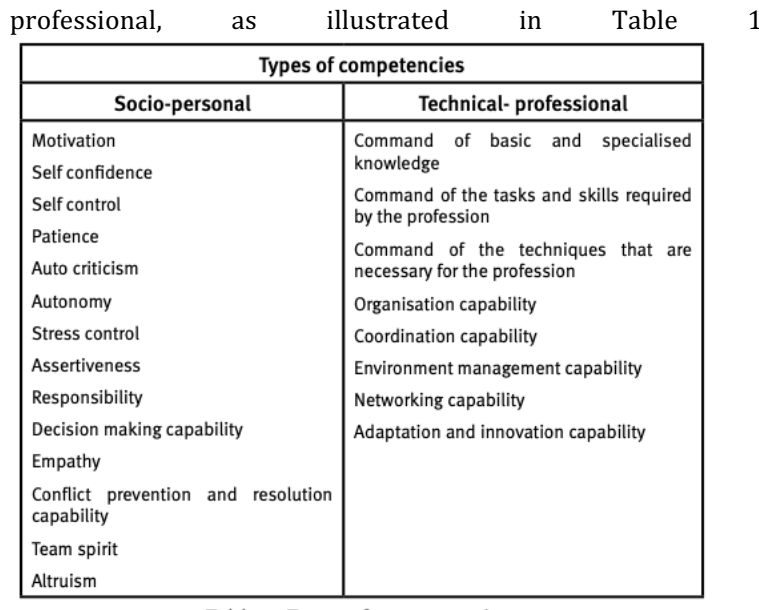

Table 1. Types of competencies.

These authors define emotional competencies as "the set of knowledge, capabilities, skills, and attitudes that are necessary to understand, express, and regulate emotional phenomena in an appropriate way. These competencies are important aspects for effective personal and professional development and can help to combat hard times in life in a more successful way. Among those aspects that are favoured by emotional competencies are the learning processes, interpersonal relationships and problem resolution, as well as working properly and keeping the job “(Bisquerra \& Pérez 2007).

In his research, Gomila (2014) considers that the emotional dimension is "the auto-perception a person has of his/her emotional status. It goes from extreme sadness, frustration, depression, to excellent enthusiasm, joy, happiness, etc. The 
blocks of emotional competencies can be seen in Figure 1

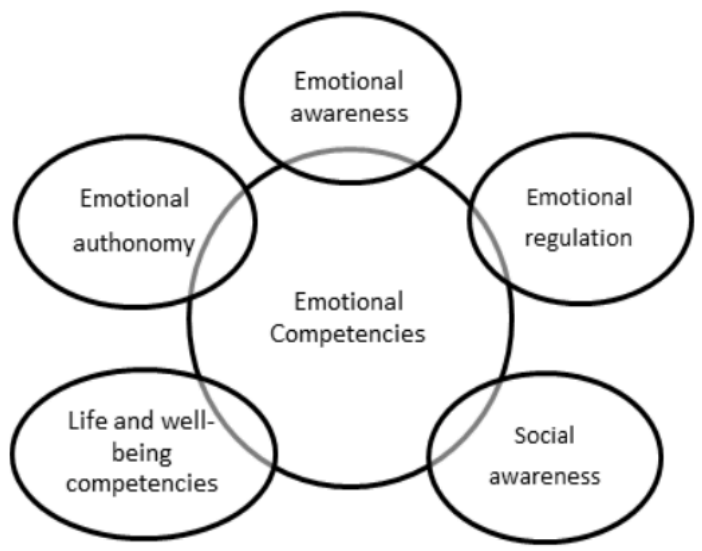

Figure 1. Block of emotional competencies.

Table 2 describes and summarises the different types of emotional competencies.

\begin{tabular}{|c|c|c|}
\hline $\begin{array}{c}\text { Blocks of } \\
\text { competencies }\end{array}$ & Description & Competencies \\
\hline $\begin{array}{l}\text { Emotional } \\
\text { awareness }\end{array}$ & $\begin{array}{l}\text { Capacity to be aware of } \\
\text { your own emotions and } \\
\text { the emotions of others, } \\
\text { including the skill to } \\
\text { capture the emotional } \\
\text { climate in a certain context. }\end{array}$ & $\begin{array}{l}\text { Awareness of own emotions } \\
\text { Give a name to emotions } \\
\text { Understand the emotions of } \\
\text { the others. }\end{array}$ \\
\hline $\begin{array}{l}\text { Emotional } \\
\text { regulation }\end{array}$ & $\begin{array}{l}\text { Capacity to manage } \\
\text { emotions in an appropriate } \\
\text { way. It implies being } \\
\text { aware of the relationship } \\
\text { between emotion, cognition } \\
\text { and behaviour, having } \\
\text { good coping strategies, } \\
\text { capacity to self generate } \\
\text { positive emotions, etc. }\end{array}$ & $\begin{array}{l}\text { To be aware of the interaction } \\
\text { between emotion, cognition } \\
\text { and behaviour } \\
\text { Emotional expression } \\
\text { Emotional regulation } \\
\text { Coping skills } \\
\text { Competency to generate } \\
\text { positive emotions }\end{array}$ \\
\hline $\begin{array}{l}\text { Emotional } \\
\text { autonomy }\end{array}$ & $\begin{array}{l}\text { It can be understood as a } \\
\text { broad concept that includes } \\
\text { a set of characteristics and } \\
\text { elements related to personal } \\
\text { self management, among } \\
\text { which are self esteem, a } \\
\text { positive attitude towards life, } \\
\text { responsibility, the capacity } \\
\text { to analyse social norms } \\
\text { critically, the capacity to } \\
\text { look for help and resources } \\
\text { and emotional self efficacy }\end{array}$ & $\begin{array}{l}\text { Self-esteem } \\
\text { Self-motivation } \\
\text { Positive attitude } \\
\text { Responsibility } \\
\text { Emotional self efficacy } \\
\text { Critical analysis of social norms } \\
\text { Resilience to face negative } \\
\text { situations in life }\end{array}$ \\
\hline $\begin{array}{c}\text { Social } \\
\text { competency }\end{array}$ & $\begin{array}{l}\text { Capacity to keep good } \\
\text { relationships with other } \\
\text { persons. This implies } \\
\text { having a command of } \\
\text { social skills, a capacity for } \\
\text { effective communication, } \\
\text { respect, assertiveness, etc }\end{array}$ & $\begin{array}{l}\text { To have a command of basic } \\
\text { social skills } \\
\text { Respect for the others } \\
\text { To practice receptive } \\
\text { communication } \\
\text { To practice expressive } \\
\text { communication } \\
\text { To share emotions } \\
\text { Pro-social behaviour and } \\
\text { cooperation } \\
\text { Assertiveness } \\
\text { Conflict prevention and } \\
\text { resolution } \\
\text { Capacity to manage emotional } \\
\text { situations }\end{array}$ \\
\hline $\begin{array}{l}\text { Competencies } \\
\text { for life and well- } \\
\text { being }\end{array}$ & $\begin{array}{l}\text { Capacity to adopt an } \\
\text { appropriate and responsible } \\
\text { behaviour to face the daily } \\
\text { challenges life has to offer } \\
\text { in an effective way, whether } \\
\text { private, professional or } \\
\text { social, as well as those } \\
\text { exceptional situations we } \\
\text { come across. They help } \\
\text { us to organise our life in a } \\
\text { healthier and more balanced } \\
\text { way, with satisfactory or } \\
\text { well-being experiences }\end{array}$ & $\begin{array}{l}\text { To set adaptable targets } \\
\text { Decision making in personal, } \\
\text { family, academic, professional, } \\
\text { social and free time in daily life } \\
\text { To look for help and resources } \\
\text { Active, responsible, critical } \\
\text { and committed citizenship } \\
\text { Subjective } \\
\text { Contribute actively to the } \\
\text { well-being of the community } \\
\text { (family, friends, society). }\end{array}$ \\
\hline
\end{tabular}

Table 2. Emotional competencies (Bisquerra \& Pérez 2007).

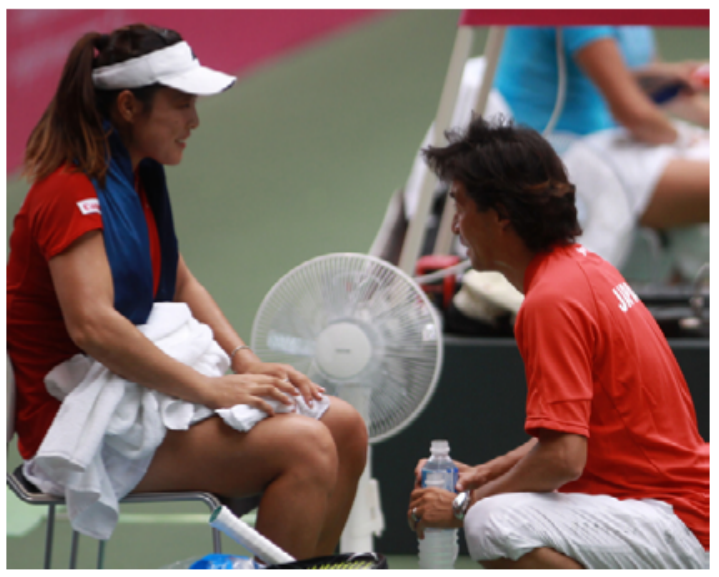

CONCLUSION

This paper supports Martens' (2002) notion that the role of the coach is much more than just his/her player's record in competition. The author considers that successful coaches help athletes to acquire and maintain skills that allow the player to have a command of new skills and enjoy competing in match play. Successful coaches are not only responsible for teaching strategies and methodologies on court but also a key responsibility of theirs is to develop and educate their player with the skills that will equip them to prosper in life on and off the tennis court. A coaches' emotional competences play a key role in the teaching-learning process. Continuous improvement of these competencies is essential for a coach to shape and develop a player's character and personality for all aspects of life.

\section{REFERENCES}

Bisquerra, R. \& Pérez, N. (2007). Las competencias emocionales. Educación XXI, $\quad 10, \quad 61$ 82.https://doi.org/10.5944/educxx1.1.10.297

Busser, J. A. \& Carruthers, C. P. (2010) Youth sport volunteer coach motivation. Managing Leisure, 15(1-2), 128-139. https://doi.org/10.1080/13606710903448210

Gallwey, W. T. (1974). El Juego Interior del tenis (1a Ed.). New York: Random House.

Gomila, B. (2014). Músico, cuerpo y conciencia. Una visión integradora. Tesis Doctoral. Universidad de Barcelona.

Lorimer, R. (2013). The development of empathic accuracy in sports coaches. Journal of Sport Psychology in Action, 4(1), 2633..https://doi.org/10.1080/21520704.2012.706696

Martens, R. (2002). El entrenador de éxito. Barcelona: Paidotribo.

Martens, R., Christina, R. W., Harvey, J. S. \& Sharkey, B. J. (1989). El entrenador. Nociones sobre psicología pedagogía, fisiología y medicina para conocer el éxito. Barcelona: Hispano-Europea.

McLean, K. N. \& Clifford, J. M. (2012). What motivates the motivators?. An examination of sports coaches. Physical Education and Sport Pedagogy, 17(1), 2135.https://doi.org/10.1080/17408989.2010.535201

Zeigler, E. F. \& Bowie, G. V. (1983). Management competency development in sport and physical education. Philadelphia: Lea and Febiger.

RECOMMENDED ITF TENNIS ICOACH CONTENT (CLICK BELOW)

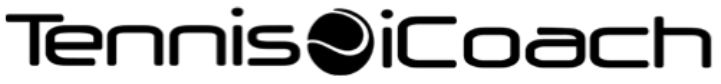


RECOMMENDED ITF TENNIS ACADEMY CONTENT (CLICK BELOW)

\section{ITF Academy}

Copyright (c) Josep Campos, Miguel Crespo \& Enric Sebastiani

2015

\section{(c) (7)}

This text is under a Creative Commons BY 4.0
You are free to Share - copy and redistribute the material in any medium or format - and Adapt the content - remix, transform, and build upon the material for any purpose, even commercially under the following terms:

Attribution: You must give appropriate credit, provide a link to the license, and indicate if changes were made. You may do so in any reasonable manner, but not in any way that suggests the licensor endorses you or your use.

CC BY 4.0 license terms summary

CCBY 4.0 license

license 